\title{
Spatial and seasonal responses of precipitation in the Ganges and Brahmaputra river basins to ENSO and Indian Ocean dipole modes: implications for flooding and drought
}

\author{
M. S. Pervez ${ }^{1,2}$ and G. M. Henebry ${ }^{2}$ \\ ${ }^{1}$ ASRC Federal InuTeq, contractor to U.S. Geological Survey (USGS), Earth Resources Observation and Science (EROS) \\ Center, 47914 252nd Street, Sioux Falls, SD 57198, USA \\ ${ }^{2}$ Geospatial Sciences Center of Excellence (GSCE) South Dakota State University, 1021 Medary Ave., Wecota Hall 506B, \\ Brookings, SD 57007-3510, USA
}

Correspondence to: M. S. Pervez (spervez@usgs.gov)

Received: 25 November 2013 - Published in Nat. Hazards Earth Syst. Sci. Discuss.: 20 February 2014

Revised: 2 December 2014 - Accepted: 20 December 2014 - Published: 28 January 2015

\begin{abstract}
We evaluated the spatial and seasonal responses of precipitation in the Ganges and Brahmaputra basins as modulated by the El Niño Southern Oscillation (ENSO) and Indian Ocean Dipole (IOD) modes using Global Precipitation Climatology Centre (GPCC) full data reanalysis of monthly global land-surface precipitation data from 1901 to 2010 with a spatial resolution of $0.5^{\circ} \times 0.5^{\circ}$. The GPCC monthly total precipitation climatology targeting the period 1951-2000 was used to compute gridded monthly anomalies for the entire time period. The gridded monthly anomalies were averaged for the years influenced by combinations of climate modes. Occurrences of El Niño alone significantly reduce ( $88 \%$ of the long-term average (LTA)) precipitation during the monsoon months in the western and southeastern Ganges Basin. In contrast, occurrences of La Niña and co-occurrences of La Niña and negative IOD events significantly enhance (110 and $109 \%$ of LTA in the Ganges and Brahmaputra Basin, respectively) precipitation across both basins. When El Niño co-occurs with positive IOD events, the impacts of El Niño on the basins' precipitation diminishes. When there is no active ENSO or IOD events (occurring in 41 out of 110 years), precipitation remains below average (95\% of LTA) in the agriculturally intensive areas of Haryana, Uttar Pradesh, Rajasthan, Madhya Pradesh, and Western Nepal in the Ganges Basin, whereas precipitation remains average to above average (104\% of LTA) across the Brahmaputra Basin. This pattern implies that a regular water deficit is likely, especially in the Ganges Basin, with impli-
\end{abstract}

cations for the agriculture sector due to its reliance on consistent rainfall for successful production. Historically, major droughts occurred during El Niño and co-occurrences of El Niño and positive IOD events, while major flooding occurred during La Niña and co-occurrences of La Niña and negative IOD events in the basins. This observational analysis will facilitate well-informed decision making in minimizing natural hazard risks and climate impacts on agriculture, and supports development of strategies ensuring optimized use of water resources in best management practice under a changing climate.

\section{Introduction}

In the Ganges and Brahmaputra basins, water is the single most important natural resource, and its availability is mostly driven by the Indian summer monsoon which significantly varies spatially and temporally. Around $60-80 \%$ of the total annual precipitation accumulates during the summer monsoon months of June-September (Immerzeel, 2008), crucial for the over half of a billion people who live in the basin and rely on precipitation and snowmelt for their livelihoods and ecosystem services. Therefore, information on the spatial and temporal distribution and variations of precipitation is important for water management and environmental hazard monitoring on a local to regional scale. The Indian monsoon is intertwined and interacts with global-scale 
circulations linked to conditions in both the Pacific and Indian oceans, in particular the El Niño Southern Oscillation (ENSO) and the Indian Ocean Dipole (IOD) modes. Precipitation over the Indian continent is inversely correlated with sea surface temperature (SST) in the central and eastern equatorial Pacific, specifically measured by the standardized NIÑO3 index (SST anomaly average over $150-90^{\circ} \mathrm{W}, 5^{\circ} \mathrm{S}-$ $5^{\circ} \mathrm{N}$ region) (Ashok and Saji, 2007; Kumar et al., 1999). El Niño events generally weaken precipitation over the Indian continent through anomalous subsidence associated with the shifting of rising limb of the Walker circulation toward the anomalously warm water in the central and eastern Pacific (Chowdhury and Ward, 2004; Kumar et al., 1999; Schott et al., 2009). Ummenhofer et al. (2011b) reported that, during the past 130 years, over $85 \%$ of the El Niño events have produced anomalously dry conditions, and historically severe droughts in India have always been accompanied by El Niño events; however, the presence of El Niño did not always produce droughts (Kumar et al., 2006). On the other hand, IOD, another dominant mode of interannual variability of the tropical Indian Ocean, characterized as anomalously zonal SST gradients within the tropical Indian Ocean accompanied by strengthening or weakening of equatorial winds (Saji et al., 1999; Webster et al., 1999), influences the Indian monsoon precipitation through associated spatial shifts in the position of the atmospheric convection (Ashok et al., 2001). A positive IOD event features an anomalously warm western Indian Ocean accompanied by strengthened easterly winds along the equatorial Indian Ocean, whereas a negative IOD event features the opposite. The positive IOD events impact the Indian monsoon precipitation positively but most importantly it counteracts the monsoon reduction expected during El Niño events when it co-occurs with El Niño events (Ashok et al., 2004; Ummenhofer et al., 2011b). For example, no droughts occurred over India in 1997 despite a strong El Niño as it cooccurred with strong positive IOD event, whereas drought had occurred during a moderate El Niño event in 2002 (Kumar et al., 2006). Ashok et al. (2001) showed that IOD modulates Indian monsoon precipitation and simultaneously affects ENSO influence on the Indian summer monsoon precipitation. They concluded that IOD and ENSO have complementary effects on the Indian monsoon precipitation. Whenever the IOD influence on the Indian monsoon precipitation is high, the ENSO influence on the same is low, and vice versa. As the variabilities of the Pacific and Indian oceans are intricately linked, IOD events may occur independently or in conjunction with ENSO (Saji et al., 1999; Meyers et al., 2007; Yamagata et al., 2004; Saji and Yamagata, 2003), and may also influence the development of ENSO (Luo et al., 2008b). It has been reported that there are apparent complementary interdecadal changes between the influences of these climate modes on the Indian summer monsoon precipitation. In recent years, the characteristics of IOD are changing (Du et al., 2013), and their influence on Indian monsoon precipitation are strengthening, while the influence of ENSO on the Indian monsoon precipitation is weakening mostly because of increased frequency of co-occurrences of positive IOD with El Niño, and reduced frequency of El Niño events (Ashok et al., 2001; Kumar et al., 1999; Ummenhofer et al., 2011b; Abram et al., 2008). In the future, ENSO amplitude is not expected to change much under a warmer climate (Guilyardi et al., 2009); however, the tropospheric static stability is expected to increase under a warmer climate, which is expected to reduce the atmospheric circulation response to a SST dipole resulting in little change in the frequency of IOD events (Zheng et al., 2010), but the difference in amplitude between positive and negative IOD events could diminish (Cai et al., 2013). Therefore the interactive influences of IOD and ENSO on the Indian monsoon precipitation could change due to global warming.

While the teleconnections from the Indo-Pacific to the Indian subcontinent modulate the Indian summer monsoon precipitation, the modulations on the monsoon precipitation are not spatially uniform. ENSO events negatively impact monsoon precipitation over most of India with west-east correlation gradients between NIÑO3 SST and precipitation, whereas the IOD events have maximum impact around the monsoon trough areas and a few parts of the west coast of India (Ashok and Saji, 2007). Geographically, the Ganges and the Brahmaputra basins are oriented west to east on the Indian subcontinent, and the latter basin does not encompass monsoon trough regions. Despite a strong influence of ENSO and IOD on the all India monsoon precipitation (Ashok et al., 2001), their influence varies significantly at basin level, even IOD events have shown neutral to negative correlations with precipitation in the Brahmaputra Basin (Ashok and Saji, 2007). This apparent paradox is the focus of this study.

The present study assesses the monsoon precipitation variability within the Ganges and Brahmaputra basins, as well as occurrences of major droughts and flooding in the basins, during independent and combined occurrences of El Niño, La Niña, and IOD events over the past 110 years (19012010). In particular, first we classify the years of El Niño, La Niña, and IOD events during the study period (Meyers et al., 2007). Second, using a Monte Carlo approach, we assess where in each river basin and what time of year precipitation is significantly affected by independent or combined occurrences of El Niño, La Niña, and IOD events. Finally, we assess how the spatiotemporal variations in precipitation link to the flooding and drought occurrences in each basin as a result of climate mode forcings. This information is critical to establish seasonal predictions of flooding and drought, and for the management of water resources both in the near term and for projected climates.

\section{Study basins}

The vast system of the Ganges (longitude 73 to $88^{\circ} \mathrm{E}$ and latitude 22 to $32^{\circ} \mathrm{N}$ ) and Brahmaputra (longitude 82 to 
$98^{\circ} \mathrm{E}$, and latitude 23 to $32^{\circ} \mathrm{N}$ ) river basins has a drainage area of 1.65 million $\mathrm{km}^{2}$, spanning from the floodplains to the mountainous areas of Nepal, India, China, Bhutan, and Bangladesh. The basins are physiographically diverse and ecologically rich in natural and crop-related biodiversity. Together they support livelihoods of a rural population of over half billion through subsistence agriculture. The average annual precipitation in the Ganges Basin is $1550 \mathrm{~mm}$, and $2025 \mathrm{~mm}$ in the Brahmaputra Basin (Mirza, 2011), respectively, and is expected to increase under a warmer climate (Pervez and Henebry, 2014). As illustrated in Fig. 1, the basins exhibit wide spatial variations in precipitation. The distribution of the average June-October precipitation climatology (mm month ${ }^{-1}$ ) shows a band of accumulated high precipitation over $250 \mathrm{~mm} \mathrm{month}^{-1}$ along the foothills of the Himalayas extending from Himachal Pradesh to Eastern Nepal in the Ganges Basin. The eastern part of the Ganges Basin up to $80^{\circ} \mathrm{E}$ experiences moderate precipitation between 100 and $250 \mathrm{~mm} \mathrm{month}^{-1}$, while west of $80^{\circ} \mathrm{E}$ it is generally semiarid to arid with less than $100 \mathrm{~mm}$ month $^{-1}$ of June-October precipitation. Another high band of precipitation in the Brahmaputra Basin extends from Sikkim to Arunachal Pradesh, where over $600 \mathrm{~mm} \mathrm{month}^{-1}$ of precipitation can be found. This area covers northern West Bengal, northern Bangladesh, Meghalaya, and Arunachal Pradesh. The northern (above $30^{\circ} \mathrm{N}$ ) part of the Brahmaputra Basin over the Tibet Plateau is mostly dry, with less than $50 \mathrm{~mm} \mathrm{month}^{-1}$ of June-October precipitation. Modulated by ENSO and IOD, this unequal spatial and seasonal distribution of monsoon precipitation creates recurrent natural hazards of flooding and drought in parts of the basins, causing damage to life, property, and infrastructure. Documenting where and when precipitation in the basins is modulated by the interactive influence of these climate modes is an important step toward minimizing natural hazard risks and climate impacts under a changing climate.

\section{Methods and data used}

We extracted Global Precipitation Climatology Centre (GPCC) full data reanalysis version 6.0 monthly land-surface precipitation data for the period $1901-2010$ at $0.5^{\circ} \times 0.5^{\circ}$ spatial resolution from Deutscher Wetterdienst in Germany. This GPCC monthly total precipitation record is the gaugeanalysis product derived from quality controlled station data. The data set is the most accurate in situ precipitation reanalysis data set of GPCC (Schneider et al., 2011). The monthly gridded data set was extracted for the Ganges and Brahmaputra basins, and monthly gridded climatology was derived targeting the period 1951-2000. The climatology was used to derive gridded monthly total precipitation anomalies for the entire time period of 1901-2010. The areal mean of the total monthly anomalies were computed by basin to derive basinspecific anomaly time series of the total monthly precipita- tion. The analyses were performed at the input spatial resolution of $0.5^{\circ} \times 0.5^{\circ}$; however, the presented analysis results were spatially interpolated to $0.1^{\circ} \times 0.1^{\circ}$, employing the inverse distance weighting (IDW) method to enhance the visualization. The IDW method was preferred over more spatially informed methods like kriging or co-kriging because our initial tests yielded no significant improvements from geo-interpolated results given the large area of the basins.

The occurrences of ENSO and IOD events are largely independent but may co-occur in the same year (Saji et al., 1999; Meyers et al., 2007); therefore, the years need to be classified when the ENSO and IOD events occur either at the same time or independently. Meyers et al. (2007) argued that the year classification method can be statistical but needs to consider the upwelling patterns of the Indo-Pacific, while others (Ashok and Saji, 2007) used ENSO indicators and the IOD mode index to classify the years statistically. We reconciled three sources of monthly SST anomalies over the $\mathrm{NINOO} 3$ region that were defined/used by earlier researchers (Kaplan et al., 1998; Reynolds et al., 2002; Trenberth, 1997) to derive a seamless NIÑO3 index as the indicator of ENSO for the period 1901-2010. For the Indian Ocean, we derived an SST anomaly difference index for the IOD modes using the areal average SST anomalies of the eastern $\left(90-110^{\circ} \mathrm{E}\right.$, $10^{\circ} \mathrm{S}$-Equator) and western $\left(50-70^{\circ} \mathrm{E}, 10^{\circ} \mathrm{S}-10^{\circ} \mathrm{N}\right)$ zones in the Indian Ocean defined by Saji et al. (1999) for the same period. The monthly IOD mode index time series was derived from the HadISST 1.1 data set - a historical SST data set compiled by the Hadley Centre for the period 1871 to present (Rayner et al., 2003). Both the NIÑO3 index and IOD mode index were normalized by their standard deviation. These time series were subset for the months June-October because the ENSO and IOD evolve during these months (Saji et al., 1999). We used these two indices to classify the years when El Niño, La Niña, and positive and negative IOD occurred, co-occurred, or did not develop. The years were classified when the 3-month moving average values of the indices were outside \pm 1 standard deviation (Meyers et al., 2007). Respective indices of above 1 standard deviation were considered as El Niño or positive IOD, indices of below 1 standard deviation were considered as La Niña or negative IOD, and any indices in between \pm 1 standard deviation were considered as no active ENSO or IOD events (neutral). The classified years for El Niño, La Niña, and IOD modes are provided in Appendix A. The climate-mode-specific classification of the years were in agreement with the years classified in other studies (Ashok and Saji, 2007; Rao et al., 2002; Ashok et al., 2004; Meyers et al., 2007; Ummenhofer et al., 2011a). To analyze how precipitation was modulated by the interactive influence of these climate modes, we averaged the gridded monthly anomalies for the years classified for the respective climate modes. The statistical significance of these averaged anomalies was analyzed using the Monte Carlo approach and a two-tailed $t$ test. 


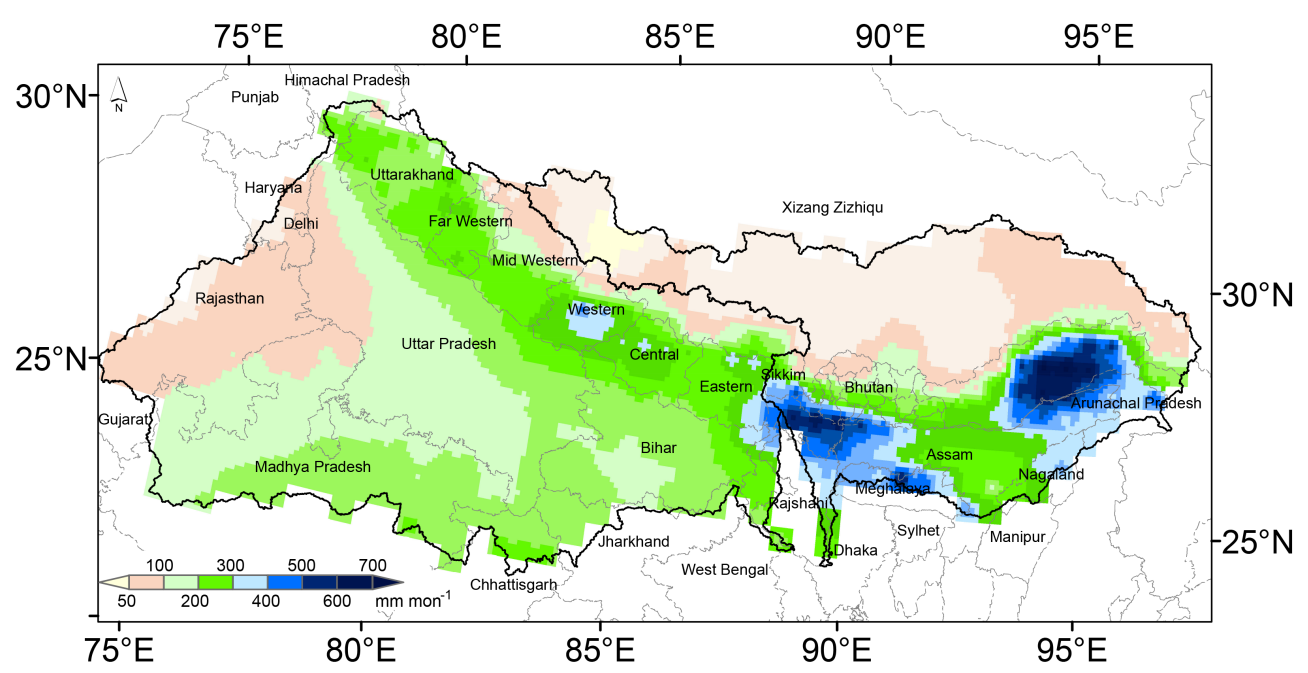

Figure 1. The Ganges and the Brahmaputra river basins overlaid by administrative boundaries. The June-October mean precipitation climatology (1950-2000) in mm month ${ }^{-1}$ is shown by the background colors.

\section{Results and discussion}

\subsection{Basin precipitation anomalies}

Table 1 presents the basin-wide areal average June-October total precipitation in millimeters as a result of the interactive influence of the ENSO and IOD. In the table, letter G denotes precipitation for the Ganges Basin and letter B denotes precipitation for the Brahmaputra Basin. The observed precipitation influenced by the respective climate mode combinations was compared with the basins' long-term average (LTA) (1951-2000) for June-October total precipitation. The Ganges and Brahmaputra basins' LTA precipitation was 1004.5 and $1090.3 \mathrm{~mm}$, respectively. During independent occurrences of El Niño, Ganges precipitation decreased to $882.4 \mathrm{~mm}$ or $88 \%$ of the LTA, while Brahmaputra precipitation fell slightly below its LTA $(1080.4 \mathrm{~mm}$ or $99 \%$ of the LTA). The precipitation increased in both basins when El Niño co-occurred with positive IOD. Ashok et al. (2001) inferred that during El Niño years, subsidence occurs over the Indian region with a strongest-to-weakest gradient from west to east (Fig. 2b of Ashok et al., 2001), resulting in reduced precipitation in the Ganges Basin but only slightly reduced precipitation in the Brahmaputra Basin. They also inferred that the IOD phenomenon modulates the meridional circulation by inducing convergence/divergence patterns over the Bay of Bengal during positive/negative IOD events, and when El Niño co-occurs with positive IOD, the ENSO-induced anomalous subsidence is neutralized or reduced by the anomalous IOD-induced convergence over the Bay of Bengal. The above phenomenon helps improve precipitation in both basins during co-occurrence of El Niño and positive IOD events compared to the precipitation during $\mathrm{El}$ Niño events only. In contrast, occurrences of La Niña and co-occurrences of La Niña and negative IOD produced ex- cessive precipitation in both basins $(1103.2 \mathrm{~mm}$ or $110 \%$ of LTA in the Ganges and $1185.8 \mathrm{~mm}$ or $109 \%$ of LTA in the Brahmaputra).

During occurrences of individual positive IOD events, the IOD-induced convergence resulted in enhanced precipitation in the Ganges Basin (1039.2 or $103 \%$ of LTA). However, the precipitation in the Brahmaputra Basin declined (1016.8 mm or $93 \%$ of LTA). The reason for this decline is that the IOD-induced convergence in the Bay of Bengal impacts the mean regions of the monsoon trough (Ashok and Saji, 2007), which overlaps mostly with the Ganges Basin. The mean monsoon trough region is shown in Fig. 1 of Rajkumar and Narasimha (1996). However, during occurrences of negative IOD events, precipitation was enhanced in the Brahmaputra Basin (1116.2 mm or $102 \%$ of LTA) but remained average in the Ganges Basin (996.5 mm or $99 \%$ of LTA) compared to the precipitation during positive IOD events in the respective basins.

In years with neutral climate modes when neither ENSO nor IOD is active, precipitation in these two basins is characterized differently. Precipitation was lower than LTA (955.5 mm or $95 \%$ of LTA) in the Ganges Basin but higher than LTA in the Brahmaputra Basin (1132.5 mm or $104 \%$ of LTA). Neutral climate modes occurred in 41 years out of 110 (37\% of the time), which implies that frequent deficit precipitation is likely in the Ganges Basin.

\subsection{Spatial variation}

There were apparent spatial differences for both the ENSO and IOD influence on precipitation over the Indian continent (Ashok and Saji, 2007). It is therefore informative to explore the spatial variability of the precipitation anomalies when influenced by phases of ENSO and IOD at the same time or independently. To understand the relative spa- 
Table 1. Composite of the June-October total precipitation ( $\mathrm{mm})$ when El Niño, La Niña, and positive and negative IOD events occurred, co-occurred, or did not develop along with the observed number of years $(n)$ in each category indicated. The observed years for each category are provided in Appendix A. The basin precipitation was not computed for the co-occurrences of El Niño and negative IOD events, and of La Niña and positive IOD events because of the small number of observed years for these categories.

\begin{tabular}{|c|c|c|c|c|}
\hline & Negative IOD (nIOD) & Average & Positive IOD (pIOD) & $\begin{array}{l}\text { All El Niño/La Niña } \\
\text { years }\end{array}$ \\
\hline \multirow[t]{4}{*}{ El Niño } & [El Niño \& nIOD] & [El Niño] & [El Niño \& pIOD] & [All El Niño years] \\
\hline & Observed years $(n): 2$ & Observed years $(n): 8$ & Observed years $(n): 12$ & Observed years $(n): 22$ \\
\hline & & G: 882.4 mm (88\%) & G: $943.2 \mathrm{~mm}(94 \%)$ & G: $912.8 \mathrm{~mm}(91 \%)$ \\
\hline & & B: $1080.4 \mathrm{~mm}(99 \%)$ & B: $1112.9 \mathrm{~mm}(102 \%)$ & B: $1096.6 \mathrm{~mm}(101 \%)$ \\
\hline \multirow[t]{4}{*}{ None } & {$[\mathrm{nIOD}]$} & [average] & {$[\mathrm{pIOD}]$} & \\
\hline & Observed years $(n): 17$ & Observed years $(n): 41$ & Observed years $(n): 9$ & \\
\hline & G: $996.5 \mathrm{~mm}(99 \%)$ & G: $955.9 \mathrm{~mm}(95 \%)$ & $\mathrm{G}: 1039.2 \mathrm{~mm}(103 \%)$ & \\
\hline & B: $1116.2 \mathrm{~mm}(102 \%)$ & B: $1132.5 \mathrm{~mm}(104 \%)$ & B: 1016.8 mm (93\%) & \\
\hline \multirow[t]{4}{*}{ La Niña } & [La Niña \& nIOD] & [La Niña] & [La Niña \& pIOD] & [All La Niña years] \\
\hline & Observed years $(n): 10$ & Observed years $(n): 9$ & Observed years $(n): 2$ & Observed years $(n): 21$ \\
\hline & G: $1094.3 \mathrm{~mm}(109 \%)$ & G: $1103.2 \mathrm{~mm}(110 \%)$ & & G: $1098.7 \mathrm{~mm}(109 \%)$ \\
\hline & B: $1185.7 \mathrm{~mm}(109 \%)$ & B: $1185.8 \mathrm{~mm}(109 \%)$ & & B: $1116.2 \mathrm{~mm}(109 \%)$ \\
\hline \multirow{4}{*}{$\begin{array}{l}\text { All pIOD/ } \\
\text { nIOD years }\end{array}$} & [All nIOD years] & & [All pIOD years] & \\
\hline & Observed years $(n): 29$ & & Observed years $(n): 23$ & \\
\hline & G: $1045.4 \mathrm{~mm}(104 \%)$ & & G: $991.2 \mathrm{~mm}(99 \%)$ & \\
\hline & B: $1150.9 \mathrm{~mm}(106 \%)$ & & B: $1064.8 \mathrm{~mm}(97 \%)$ & \\
\hline
\end{tabular}

Note: G denotes the Ganges precipitation and B denotes the Brahmaputra precipitation. Percent precipitation of the long-term average (LTA) (1950-2000) for June-October is in parentheses. The Ganges LTA for June-October total was $1004.5 \mathrm{~mm}$, and $1090.3 \mathrm{~mm}$ for the Brahmaputra. pIOD/nIOD denotes positive/negative Indian Ocean Dipole.

tial influence of ENSO and IOD on the basin precipitation, the average June-October precipitation anomalies are presented in Figs. 2 and 3. To determine if the precipitation anomalies were significantly modified by the influence of the ENSO-IOD combinations, we adopted the modified Monte Carlo testing method of Ummenhofer et al. (2011a). For any combination of ENSO-IOD, $n$ represents the number of occurrences of that combination. For each pixel (there were $5370.5^{\circ} \times 0.5^{\circ}$ pixels) in the study basins, from all years (110 years total), we randomly picked $n$ years and took the mean. The process was repeated 10000 times to produce a probability density function of expected average JuneOctober precipitation anomalies. The expected anomalies for each pixel and for each ENSO-IOD combination were then compared with the mean anomalies of the observed years $(n)$ for the respective combination. The comparisons of the anomalies for all 537 pixels are presented in Fig. 2. The gray shading in Fig. 2 denotes the 10\% lower bounds and $90 \%$ upper bounds of $80 \%$ confidence intervals estimated from a two-tailed $t$ test for the randomly generated distribution. The gray shaded area varies between ENSO-IOD combinations because of the differences in randomly generated distributions depending on the number of members $n$. Figure 2 shows that where the blue dots lie outside the gray shaded area the anomalies are significantly different because of the influence of ENSO-IOD combinations. It also implies that the pixels, where their values lie outside the gray shaded area, are the places where precipitation is significantly modified by the interactive influence of the ENSO and IOD. We identified these pixels and plotted them in Fig. 3.

In Fig. 3a, anomalously dry conditions dominate in the western and southeastern parts of the Ganges Basin and the southern parts of the Brahmaputra Basin during years with El Niño. Haryana, Rajasthan, western Uttar Pradesh, and Madhya Pradesh in the Ganges Basin experience reductions in precipitation between 30 and $40 \mathrm{~mm} \mathrm{month}^{-1}$ (reduction of 21 to $28 \%$ from LTA with 72 to $79 \%$ of the LTA precipitation). Precipitation also declines in Uttarakhand, Far Western Nepal, Mid-Western Nepal, and the eastern part of the basin in Bihar and western West Bengal by around $35 \mathrm{~mm}^{\text {month }}{ }^{-1}$ (reduction of $14 \%$ from LTA with $86 \%$ of the LTA precipitation). In Brahmaputra, Arunachal Pradesh, western Assam, northern West Bengal, and northern Bangladesh, precipitation declines by more than $45 \mathrm{~mm} \mathrm{month}^{-1}$ (reduction of $10 \%$ from LTA with $90 \%$ of the LTA precipitation). Climatologically, the western part of the Ganges Basin encompassing Haryana, Rajasthan, and Madhya Pradesh can be considered arid to semiarid with average June-October precipitation of around $143 \mathrm{~mm} \mathrm{month}^{-1}$, while regions in Uttarakhand, Nepal, Bihar, and West Bengal in the Ganges receive over $250 \mathrm{~mm} \mathrm{month}^{-1}$ of precipitation. In the Brahmaputra Basin, northern West Bengal, northern Bangladesh, western Assam, and western Arunachal Pradesh are the wettest regions and receive over $450 \mathrm{~mm} \mathrm{month}^{-1}$ of precipitation dur- 

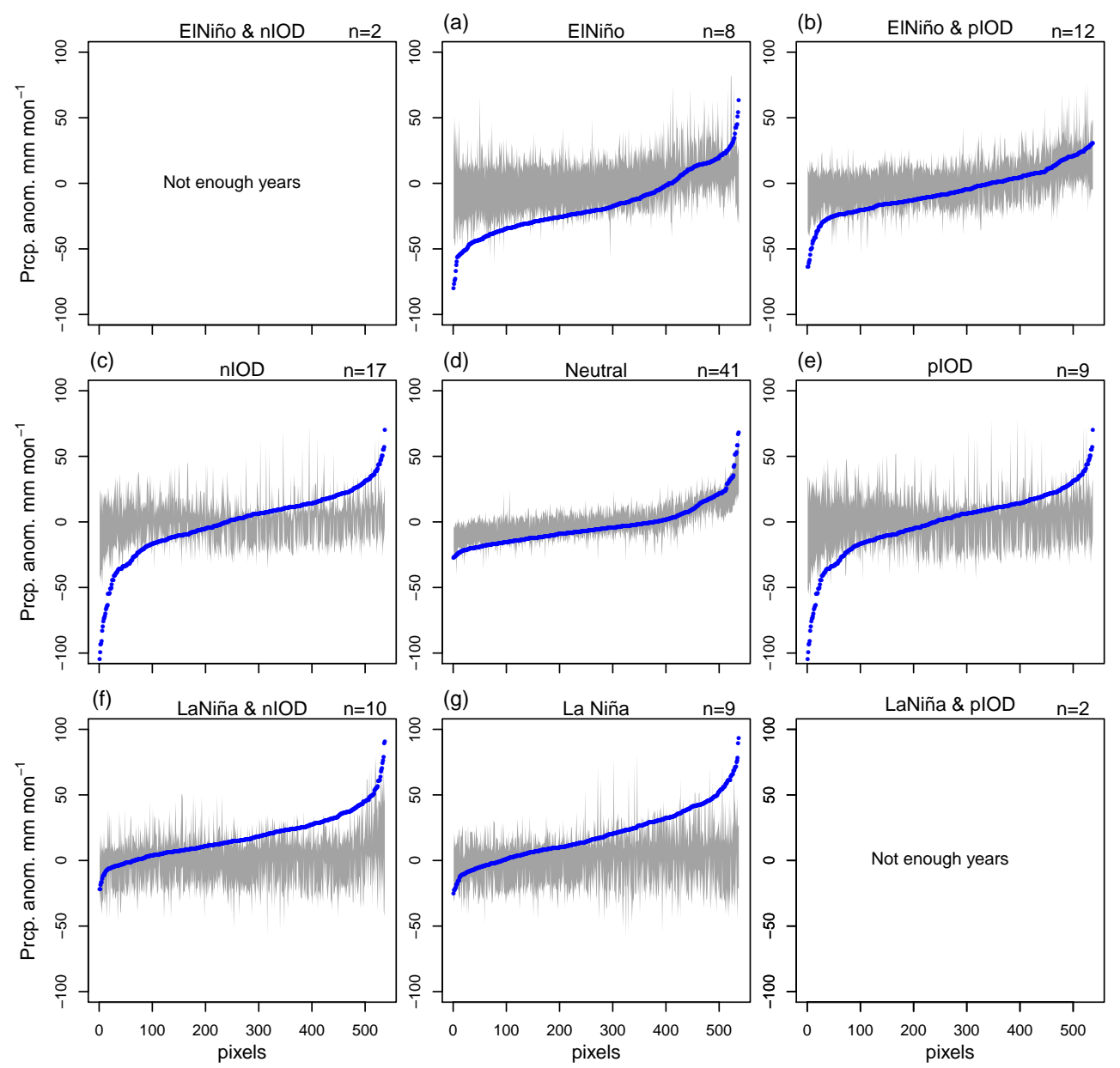

Figure 2. Composite of the mean precipitation anomaly for June-October for each pixel in the basins when El Niño, La Niña, and positive or negative IOD occurred, co-occurred, or did not develop. The number of observed years for each ENSO-IOD combination is indicated with $n$. Combination-specific precipitation anomalies $\left(\mathrm{mm} \mathrm{month}^{-1}\right)$ are shown with blue dots, 10 and $90 \%$ lower and upper bounds of the pixel-specific long-term mean precipitation as determined by Monte Carlo testing and a two-tailed $t$ test at $80 \%$ confidence level is shown with gray shading. Where the blue dots lie outside the gray shaded area, the precipitation anomaly values are significantly different from the long-term variance.

ing June-October. Although the reduction in precipitation in Haryana, Rajasthan, western Uttar Pradesh, and Madhya Pradesh during El Niño years is relatively smaller than the precipitation reduction in the other regions in the Ganges Basin, the impacts of El Niño in these regions can be stronger since these areas are comparatively drier and receive less precipitation than the rest of the basin area. These areas are also the most agriculturally intensive areas in the Ganges Basin and rely on precipitation for successful agricultural production (Thenkabail et al., 2009). When El Niño co-occurs with positive IOD, the deficit precipitation in Haryana, western Uttar Pradesh, Madhya Pradesh, and Bihar disappears, but it remains significantly below LTA in Uttarakhand, Rajasthan, and Central Nepal in the Ganges Basin (Fig. 3b). During El Niño the ascending motion of the tropical Walker circulation shifts eastward from its usual position over Indonesia to the central Pacific (Goswami, 1998), which in turn modifies the Hadley circulation and creates anomalous subsidence over the Indian continent (Ashok et al., 2004). This El Niño-induced subsidence reduces precipitation in both basins. When El Niño co-occurs with positive IOD, a single strong Walker cell is formed over the equatorial Indian Ocean with descending motion in the east and ascending motion in the west. It neutralizes or reduces El Niño-induced subsidence precipitation and therefore minimizes the impacts of El Niño on the precipitation in both basins, but more so in the monsoon trough regions in the Ganges Basin (Ashok et al., 2004). In contrast, consistently wet conditions occurred in both basins during the occurrences of La Niña and cooccurrence of La Niña and negative IOD, leading to significantly above-average precipitation along the high precipitation band areas of the foothills of the Himalayas across the basins (Fig. 3f and g). During La Niña events, Uttarakhand, Uttar Pradesh, Western Nepal, Bihar, and western West 

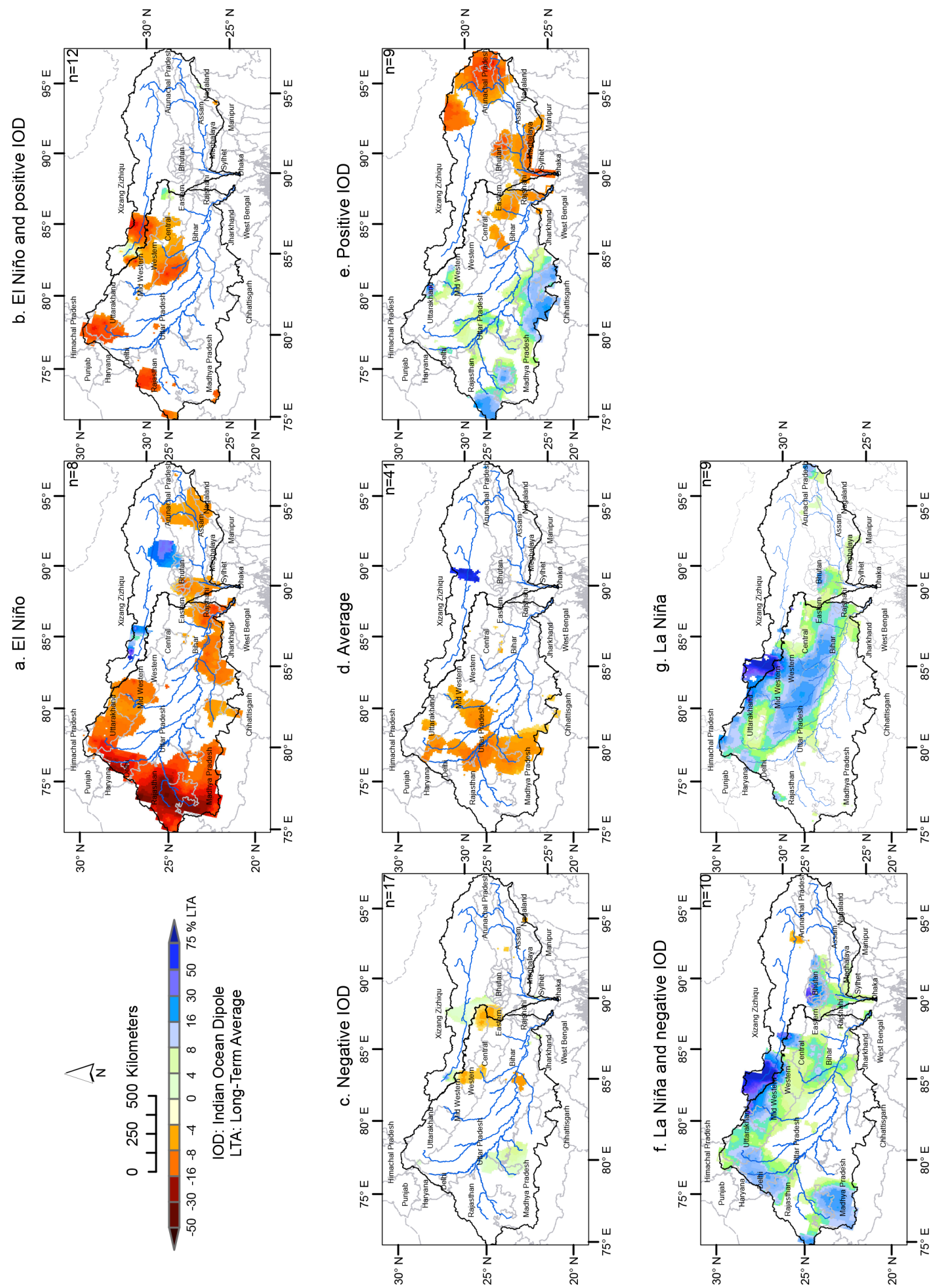

Figure 3. Composite of the spatially distributed mean June-October precipitation anomalies (\% of LTA) when El Niño, La Niña, and positive or negative IOD occurred, co-occurred, or did not develop. The number of observed years for each ENSO-IOD combination is indicated with $n$. The only anomalies shown are those significantly different from the long-term variance as determined by Monte Carlo testing and a two-tailed $t$ test at $80 \%$ confidence level. 
Bengal in the Ganges Basin receive an increase of over $40 \mathrm{~mm} \mathrm{month}^{-1}$ (increase of $16 \%$ from LTA with $116 \%$ of the LTA precipitation) of precipitation. On the other hand, precipitation in Arunachal Pradesh and Meghalaya in the Brahmaputra Basin increases marginally, but it increases significantly ( $>60 \mathrm{~mm} \mathrm{month}^{-1}$ or $14 \%$ from LTA equivalent to $114 \%$ of LTA) over western Assam, northern West Bengal, Bhutan, and northern Bangladesh. The precipitation in these regions is also positively impacted by co-occurrences of La Niña and negative IOD. However, in parts of Madhya Pradesh and Rajasthan, precipitation increases significantly during co-occurrences of La Niña and negative IOD, but it does not increase as much during individual occurrences of La Niña. During La Niña events, the equatorial eastern Pacific Ocean is anomalously cold, but the equatorial western Pacific, including parts of the eastern Indian Ocean, is anomalously warm. With such a distribution of SST anomalies, the Walker circulation becomes well defined with the ascending motion of its usual location over Indonesia (Goswami, 1998). The surface wind increases over the Arabian Sea, which helps develop the Hadley cell; therefore, convection activities increase and cause anomalous positive precipitation in the basins (Ashok et al., 2004).

During years without active ENSO or IOD events (neutral years), although precipitation was observed close to LTA in most parts of the basins owing to a moderately developed Walker circulation, deficit precipitation may still prevail in the intensive agricultural regions of Rajasthan, western Utter Pradesh, and northern Madhya Pradesh (Fig. 3d). Precipitation is around $89 \%$ of the LTA (or $11 \%$ less than LTA) in these areas during the neutral conditions. During the study period, there were 41 years out of 110 (37\% of the time) when there were no active ENSO or IOD events in the Indo-Pacific Ocean. This situation is important from an agricultural perspective, implying that water deficit is likely to occur frequently with potentially damaging consequences to the agricultural sector in these regions.

Negative IOD events significantly modify precipitation in only very few places across the basins. For most places, precipitation was close to LTA or insignificantly enhanced from the LTA (Fig. 3c). However, during individual occurrences of positive IOD, precipitation in these two basins is modified differently (Fig. 3e). Precipitation increases in southern Haryana, eastern Madhya Pradesh, Jharkhand, and Chhattisgarh by around $27 \mathrm{~mm}^{\text {month }}{ }^{-1}$ or $14 \%$ more than the LTA (114\% of the LTA precipitation), while it decreases by $25 \mathrm{~mm} \mathrm{month}^{-1}$ or $8 \%$ less than LTA (92\% of the LTA precipitation) in Eastern Nepal in the Ganges Basin during positive IOD years. On the other hand, precipitation is negatively influenced by positive events of IOD in the Brahmaputra Basin, decreasing significantly $\left(52 \mathrm{~mm} \mathrm{month}^{-1}\right.$ which is $85 \%$ of the LTA or $15 \%$ less than the LTA) across the basin. During positive IOD events, the western Indian Ocean is warmer, which creates an anomalous excess ascending motion over the western equatorial Indian Ocean, which induces anomalous subsidence northward to $15^{\circ} \mathrm{N}$, which in turn triggers the ascending motion farther north, causing surplus precipitation over the monsoon trough of the Ganges Basin (Ashok et al., 2004).

\subsection{Seasonal variation}

The evolution of the ENSO and subsequent association with the Indian Ocean SST varies seasonally depending on the timing of the onset (Sooraj et al., 2009). IOD is phase locked to the boreal summer and autumn months (Saji et al., 1999). While IOD anomalies develop in JJA, they are most prominent in SON. Therefore, we examined how precipitation in these two basins responds seasonally when ENSO and IOD occur at the same time or independently. We applied Monte Carlo testing and a $t$ test described in Sect. 4.2 to estimate the statistical significance of the seasonal change in precipitation caused by the interactive influence of the ENSO-IOD. Here, the Monte Carlo test was performed by month with 25000 iterations for each month for the Ganges and Brahmaputra basins separately. The seasonal observed and expected precipitation for each ENSO-IOD combination is presented in Figs. 4 and 5 for the Ganges and Brahmaputra basins, respectively. In Figs. 4 and 5, within each category, $n$ is the number of observed years, the black line represents the longterm seasonal cycle of the basin-wide precipitation, observed values are shown with blue dots, and the mean of these observed values is indicated with a red $\mathrm{X}$. The gray shading denotes the $10 \%$ lower and $90 \%$ upper bounds of the $80 \%$ confidence interval for the randomly generated distribution. The gray shaded area varies depending on the random distributions based on number of observed years $n$ for each ENSO-IOD combination. In the month where the observed mean point (red X) lies outside the gray shaded area, precipitation is significantly modified by the interactive influence of ENSO-IOD.

In the Ganges Basin, from Fig. 4, the high precipitation during the monsoon months is apparent. During El Niño events, precipitation significantly decreases in the early and late monsoon months of June and September. Nearly $90 \%$ of the El Niño years in June and $75 \%$ of the El Niño years in September record precipitation below the long-term mean expected for those months (Fig. 4a). When El Niño occurs independently, the July-August mean precipitation was $298 \mathrm{~mm} \mathrm{month}^{-1}$, just under the long-term mean of $310 \mathrm{~mm} \mathrm{month}^{-1}$. Although the July and August mean precipitation was not significantly different from the long-term expected mean, more than half of the observed El Niño years in these two months record precipitation below the longterm mean. When El Niño and positive IOD occurred in the same year, precipitation improved over the summer monsoon months, but more so in the late monsoon months of August and September compared to the seasonal precipitation during independent El Niño years (Fig. 4b). During independent positive IOD years, a significant increase in July- 

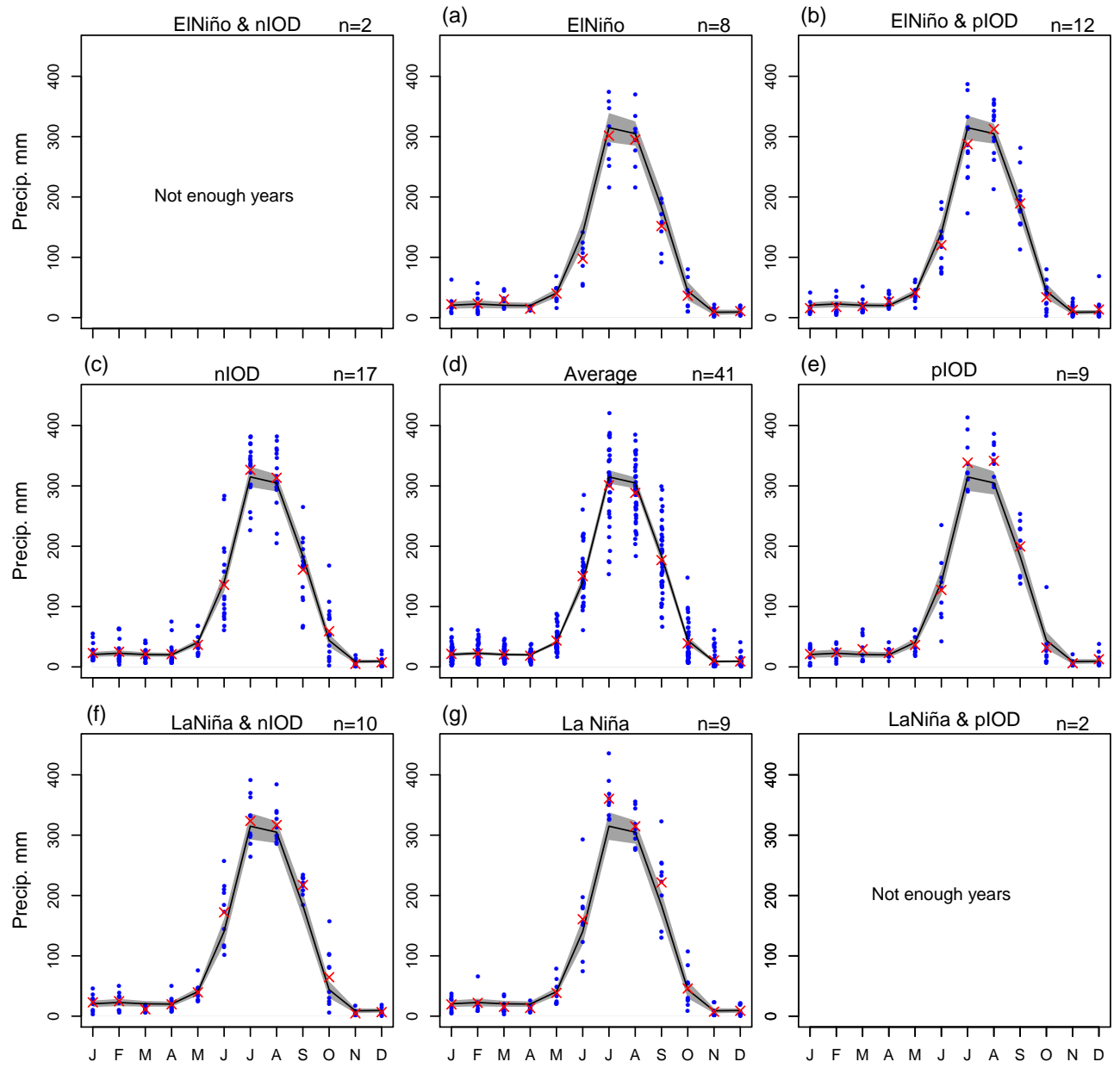

Figure 4. Composite of the Ganges Basin precipitation $(\mathrm{mm})$ by month when El Niño, La Niña, and positive or negative IOD occurred, co-occurred, or did not develop. The number of observed years for each ENSO-IOD combination is indicated with $n$. The seasonal cycle from January to December is shown for the period 1901-2010. The black line is the mean of all years (1901-2010). Within each combination, observed years $(n)$ are shown with blue dots, the red X shows the mean of the observed years, and its confidence levels are shown with gray shading as determined by Monte Carlo testing and a two-tailed $t$ test at $80 \%$ confidence interval. Where the red X lies outside the gray shaded area, the values are significantly different from the long-term variance of that month.

September precipitation is noticeable for the Ganges Basin (Fig. 4e). The July-August positive IOD years' mean precipitation increases to $340 \mathrm{~mm} \mathrm{month}^{-1}$, around $10 \%$ more than the long-term expected mean for those same months. More than $70 \%$ of the positive IOD years in July and August exceed the long-term expected mean precipitation for those months. However, when negative IOD occurs independently while above-average precipitation occurs during June-August, a notable reduction in September precipitation is apparent (Fig. 4c). Over $75 \%$ of the negative IOD years show precipitation below the composite mean for September. During years without active ENSO-IOD events, despite many years with excessive July and August precipitation, the composition observed mean is still significantly lower than the expected long-term mean during these two peak monsoon months in the Ganges Basin (Fig. 4d). Consistently above-average precipitation occurs during the summer monsoon months, including pre- and post-monsoon months when La Niña and negative IOD occur in the same year or independently (Fig. 4f, g). Significantly above-average precipitation occurs in July and September during La Niña years. Precipitation during La Niña years were not less than the expected mean for July. The mean July La Niña year precipitation was $360 \mathrm{~mm}$, which is a $17 \%$ increase from the expected July long-term mean; September precipitation increases by around $20 \%$ to $221 \mathrm{~mm}$ from the expected longterm mean, with over $77 \%$ of the La Niña year precipitation in September, exceeding the expected mean (Fig. 4g). Precipitation outside the monsoon months (December to May and November) is less than $50 \mathrm{~mm} \mathrm{month}^{-1}$ and changes insignificantly depending on the interactive influence of ENSO and IOD. 

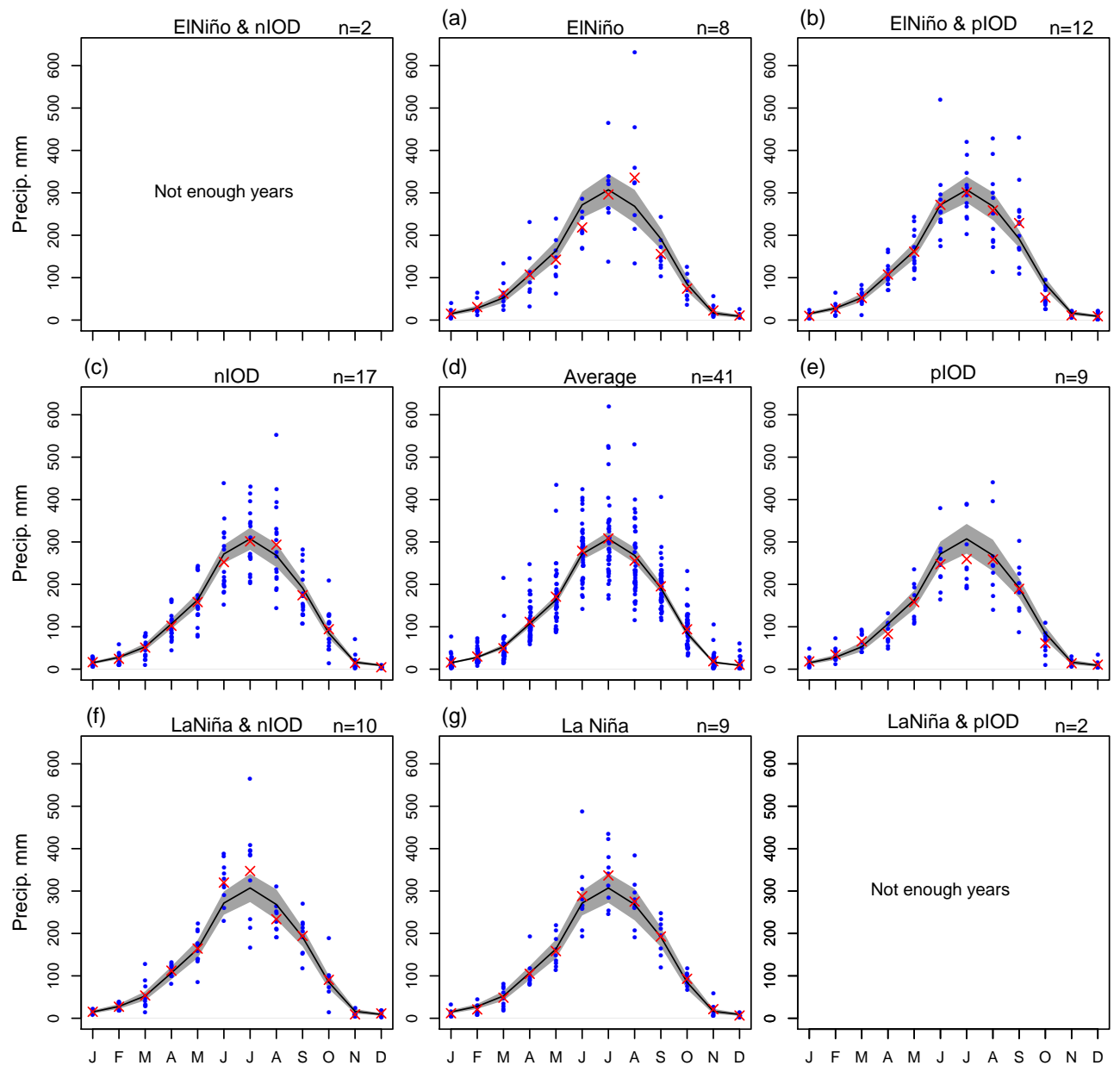

Figure 5. Composite of the Brahmaputra Basin precipitation $(\mathrm{mm})$ by month when El Niño, La Niña, and positive or negative IOD occurred, co-occurred, or did not develop. The number of observed years for each ENSO-IOD combination is indicated with $n$. The seasonal cycle from January to December is shown for the period 1901-2010. The black line is the mean of all years (1901-2010). Within each combination, observed years $(n)$ are shown with blue dots, the red X shows the mean of the observed years, and its confidence levels are shown with gray shading as determined by Monte Carlo testing and a two-tailed $t$ test at $80 \%$ confidence interval. Where the red X lies outside the gray shaded area, the values are significantly different from the long-term variance of that month.

High precipitation during the summer monsoon months in the Brahmaputra Basin makes the seasonal precipitation cycle for the Ganges and Brahmaputra similar, but the Brahmaputra Basin receives more pre-monsoon precipitation in April, May, and June. In the Brahmaputra Basin, precipitation significantly declines in May, June, and September during El Niño years and improves when El Niño co-occurs with positive IOD (Fig. 5a, b). The August mean precipitation during El Niño years may have been skewed because of an outlier. The mean June-August precipitation increases to $278 \mathrm{~mm} \mathrm{month}^{-1}$ when El Niño co-occurs with positive IOD compared to the mean for the El Niño years - a modest $3 \%$ increase - although it remains below the expected long-term mean for these same months. Unlike the Ganges, during positive IOD years, Brahmaputra precipitation significantly declines in the peak monsoon month of July, and the
June-August precipitation remains well below the long-term expected mean for the respective months (Fig. 5e). Around $75 \%$ of the positive IOD years' precipitation in June, July, and August remains below the long-term expected mean. However, precipitation improved seasonally during negative IOD years compared to positive IOD years. Nearly $50 \%$ of the June and July precipitation during negative IOD years exceeds the long-term expected mean (Fig. 5c). During years without active ENSO-IOD, precipitation remains close to the long-term expected mean throughout the seasonal cycle (Fig. 5d). During La Niña, precipitation increases in June and July, but precipitation increases more during cooccurrences of La Niña and negative IOD (Fig. 5f, g). Precipitation increases by $15 \%$ to $334 \mathrm{~mm} \mathrm{month}^{-1}$ for June and July. From our analysis, it is evident that ENSO-IOD combinations modify the July-September precipitation the most 
in the Ganges Basin, while the modifications are noticeable in June-August in the Brahmaputra Basin. During La Niña and co-occurrences of La Niña and negative IOD, precipitation exceeds $400 \mathrm{~mm}$ in the Ganges Basin only $5 \%$ of the time, while it exceeds $26 \%$ of the time in the Brahmaputra Basin, suggesting that extreme modifications in precipitation are more frequent in the Brahmaputra Basin than it is in the Ganges Basin.

\subsection{Implications for flooding and drought}

Table 2 lists occurrences of major floods and droughts in the Ganges and Brahmaputra basins from the ENSO-IOD combination during the period 1901-2010. We define a flood or drought as major when the affected area exceeds $25 \%$ of the basin area; however, the affected area is estimated empirically from the maps and published literature. Monsoon precipitation is the primary cause for flooding in these basins, especially downstream across Bangladesh; therefore, frequent flooding is expected when precipitation is positively modulated by La Niña or La Niña and negative IOD events (Webster et al., 2010). There were seven major floods in the Ganges Basin and six major floods in the Brahmaputra Basin reported when La Niña or La Niña and negative IOD was active. The occurrences of these two combinations produced flooding $36 \%$ of the time in the Ganges and $31 \%$ of the time in the Brahmaputra Basin between 1901 and 2010. These combinations were also responsible for the majority of the catastrophic floods in terms of flood severity. The floods of 1922, 1955, 1988, and 2007 were among the worst floods in history in these two basins (Hofer and Messerli, 2006; Mirza et al., 2001; Siddique et al., 1991). In agreement with Ashok et al. (2004), our findings suggest that both phases of IOD modulate precipitation positively in the Ganges Basin, but the Brahmaputra precipitation is modulated negatively by positive IOD and positively by negative IOD. Subsequently, no major floods were observed in the Brahmaputra Basin during positive IOD events. However, negative IOD events produced floods $15 \%$ of the time in the Brahmaputra Basin, while both phases of IOD events produced floods $26 \%$ of the time. Although most of these floods during IOD events can be considered non-catastrophic regarding severity, the 1998 flood was exceptional and catastrophic. In 1998, extensive flooding occurred in the basins when both the Ganges and Brahmaputra Rivers crested simultaneously (Webster et al., 2010). El Niño has been observed influencing precipitation negatively in both basins, and the lack of major floods in all of these basins during El Niño events supports this observation. However, when El Niño and positive IOD occur in the same year, precipitation can be influenced positively. There were two major flood years in the Ganges Basin and three in the Brahmaputra Basin during the El Niño and positive IOD events; the 1987 flood was extraordinary and occurred in both basins, simultaneously affecting mostly Bihar, West Bengal, Assam, and Bangladesh. (Hofer and Messerli,
2006). During years without active ENSO or IOD events, even though precipitation can be anomalously negative, especially in the peak monsoon months, the neutral conditions produced floods $4 \%$ of the time in the Ganges Basin. Precipitation is expected to be equivalent to the long-term mean in the Brahmaputra Basin during neutral conditions; subsequently, more floods (12\% of the time during neutral conditions) were noticeable in the Brahmaputra Basin. However, many of these floods (2004 and 2008) were local (Webster et al., 2010).

Drought is another natural hazard common to parts of both basins. There were 13 major droughts in the Ganges Basin and four in the Brahmaputra Basin. The majority of the droughts in the Ganges occurred when El Niño and IOD occurred at the same time or individually. These El Niño-IOD combinations produced droughts $18 \%$ of the time. Droughts were also commonly observed during neutral conditions in the Ganges. The neutral conditions produced droughts $16 \%$ of the time in the Ganges Basin. On the other hand, there were only four major droughts reported across the Brahmaputra Basin. Among these droughts, the ones in 1982, 1989, and 1994 were severe (Chowdhury and Ward, 2007). The fractions of disaster years in Table 2 indicate that both basins are vulnerable to natural disasters. The Ganges Basin is vulnerable to both flooding and drought; whereas, the Brahmaputra Basin is more vulnerable to flooding than drought. With changing characteristics of positive and negative IOD events (Ummenhofer et al., 2009), ENSO and IOD events may be predictable well in advance (Luo et al., 2008a, b). Results of this study in conjunction with long-lead predictability of the ENSO and IOD events could enable early warnings for flooding and drought risks in the region.

In general, major flooding and drought occurred in the basins in accordance with the expected excess or deficit precipitation due to the prevailing influence of ENSO and IOD at the same time or individually. However, in both basins major flooding was observed when deficit precipitation was expected due to the influence of the climate modes. During the past few decades, increasing trends of extreme heavy precipitation events have been observed (Rajeevan et al., 2008; Stocker et al., 2013). Monsoon precipitation has been increasing especially in the Ganges Basin (Moors et al., 2011), but precipitation amounts before and after the monsoon have been declining (Ramesh and Goswami, 2007), with a declining number of rainy days (Das et al., 2013). As suggested by these studies, when precipitation increases over a shorter period of time with a reduced number of rainy days, flash flooding is expected regardless of the influence by the climate modes.

\section{Conclusions}

We have documented where and when precipitation in the Ganges and Brahmaputra basins has been modulated when 


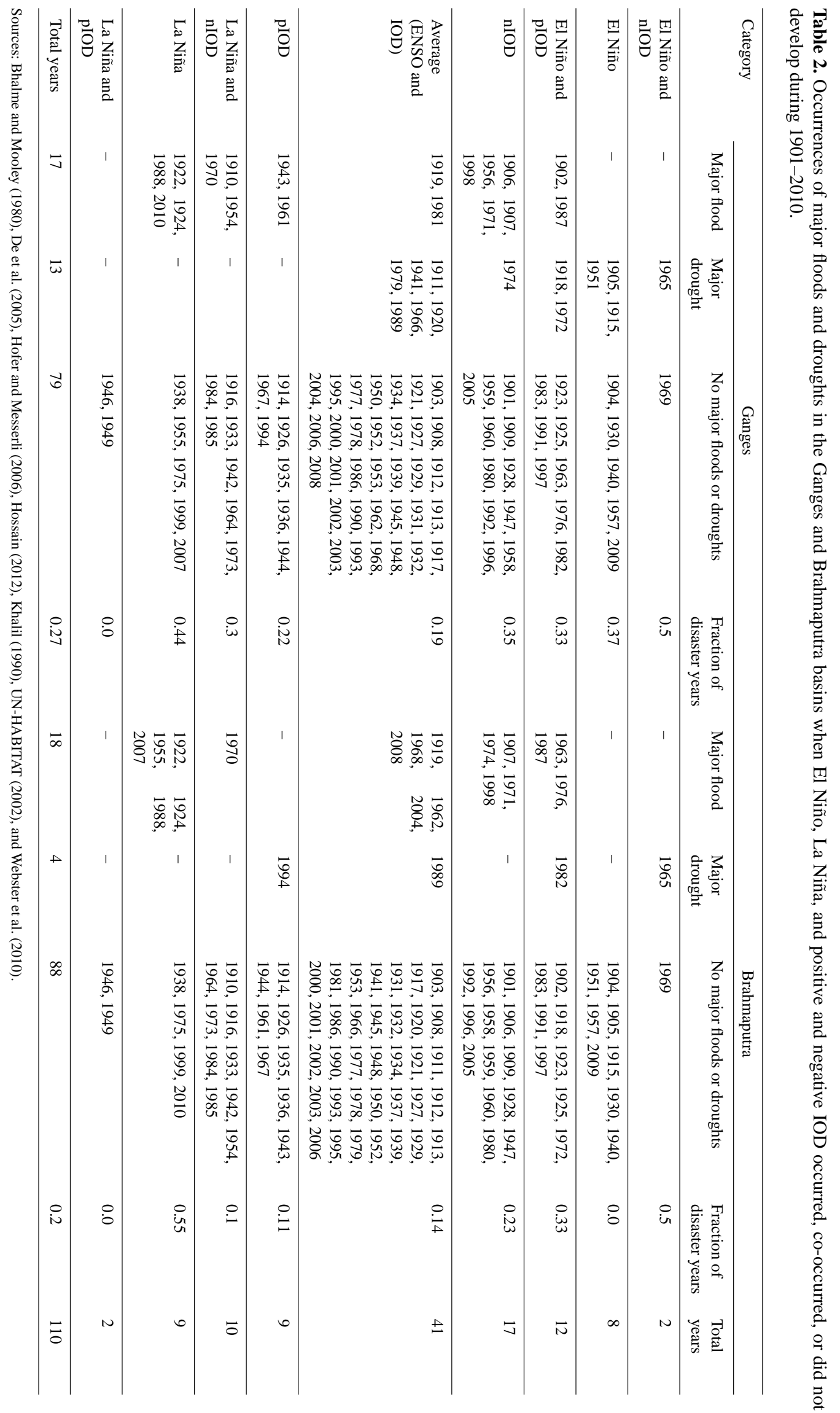


ENSO and IOD occur at the same time or individually. Importantly, deficit precipitation prevails in Uttarakhand, Far Western Nepal, Mid-Western Nepal, Haryana, western Uttar Pradesh, Rajasthan, Madhya Pradesh, Bihar, and western West Bengal in the Ganges Basin, and in Arunachal Pradesh, western Assam, northern West Bengal, and northern Bangladesh in the Brahmaputra Basin during El Niño events. The occurrences of La Niña and co-occurrences of La Niña and negative IOD produce the most precipitation over both basins. On the other hand, the occurrences of El Niño produce the most deficit precipitation regimes. However, their frequency is limited.

Perhaps the most compelling observation is that during neutral conditions when there are no active ENSO or IOD events, which occurred most frequently (37\% of the time during the study period), below-average precipitation may prevail in Rajasthan, western Uttar Pradesh, and parts of Madhya Pradesh. The occurrences of more frequent neutral conditions shape the requirements for successful agricultural production by supplemental irrigation from declining groundwater sources $(61 \%$ of irrigation water comes from groundwater) (UNEP, 2009; Rodell et al., 2009). This pattern implies that agricultural production is challenging during frequent neutral conditions because of the evident scarcity of water resources.
At the seasonal scale, in excess precipitation years during the occurrences of La Niña and co-occurrence of La Niña and negative IOD, precipitation increases during the summer monsoon months of June-September in the Ganges Basin, but in the Brahmaputra Basin, increased precipitation is noticeable in May-September. In deficit precipitation years, El Niño tends to reduce precipitation in the monsoon months of June-August, but when El Niño co-occurs with positive IOD, much of the deficit precipitation of the summer months disappears. Unlike the Ganges, during positive IOD years, Brahmaputra precipitation significantly diminishes in the peak monsoon month of July, with the mean monsoon precipitation well below the long-term expected mean. However, precipitation improved seasonally during negative IOD years more than during positive IOD years in the Brahmaputra Basin. It is evident that ENSO-IOD combinations modify the July-September precipitation the most in the Ganges Basin, while the modifications are noticeable in June-August with more frequent extreme precipitation in the Brahmaputra Basin.

We have noted occurrences of major flooding and drought as consequences of the interactive influence of ENSO and IOD. However, there are other years with similar influences by the ENSO-IOD combinations that did not produce flooding or drought. This finding implies that other factors, in addition to the climate mode influences, affect the timing and location of the precipitation that produces flooding or drought in the basins. Here, our analyses identified where and when the climate modes modulate precipitation in the basins. This information is critical for the development of early warnings for natural hazard risks and may provide information to support the development of local strategies to minimize climate mode impacts on agricultural production and rural livelihoods. 


\section{Appendix A}

Classification of observed years when El Niño, La Niña, and positive and negative Indian Ocean Dipole events occurred, co-occurred, or did not develop.

El Niño and negative IOD years: 1965, 1969.

El Niño years: 1904, 1905, 1915, 1930, 1940 1951, 1957, 2009.

El Niño and positive IOD years: 1902, 1918, 1923, 1925, 1963, 1972, 1976, 1982, 1983, 1987, 1991, 1997.

Negative IOD years: 1901, 1906, 1907, 1909, 1928, 1947, 1956, 1958, 1959, 1960, 1971, 1974, 1980, 1992, 1996, 1998, 2005.

Neutral ENSO and IOD years: 1903, 1908, 1911, 1912, 1913, 1917, 1919, 1920 1921, 1927, 1929, 1931, 1932, 1934, 1937, 1939, 1941, 1945, 1948, 1950, 1952, 1953, 1962, 1966 1968, 1977, 1978, 1979, 1981, 1986, 1989, 1990 1993, 1995, 2000, 2001, 2002, 2003, 2004, 2006, 2008.

Positive IOD years: 1914, 1926, 1935, 1936, 1943, 1944, 1961, 1967, 1994.

La Niña and negative IOD: 1910, 1916, 1933, 1942, 1954, 1964, 1970, 1973, 1984, 1985.

La Niña years: 1922, 1924, 1938, 1955, 1975, 1988, 1999, 2007, 2010.

La Niña and positive IOD years: 1946, 1949. 
Acknowledgements. This research was supported in part by the US Agency for International Development Famine Early Warning Systems Network agreement with the US Geological Survey, and in part by the Geospatial Sciences Center of Excellence at South Dakota State University. We thank these agencies for their support. We sincerely thank Gabriel Senay, James P. Verdin, James Rowland, and Michael Budde at USGS EROS for suggestions made throughout the research. We greatly appreciate the astute comments made by the anonymous reviewers and by USGS reviewers that helped us improve the manuscript considerably. Any use of trade, firm, or product names is for descriptive purposes only and does not imply endorsement by the US Government. Work performed under USGS contract G13PC00028.

Edited by: U. Ulbrich

Reviewed by: four anonymous referees

\section{References}

Abram, N. J., Gagan, M. K., Cole, J. E., Hantoro, W. S., and Mudelsee, M.: Recent intensification of tropical climate variability in the Indian Ocean, Nat. Geosci., 1, 849-853, 2008.

Ashok, K., Guan, Z., and Yamagata, T.: Impact of the Indian Ocean dipole on the relationship between the Indian monsoon rainfall and ENSO, Geophys. Res. Lett., 28, 4499-4502, 2001.

Ashok, K. and Saji, N. H.: On the impacts of ENSO and Indian Ocean dipole events on sub-regional Indian summer monsoon rainfall, Nat. Hazard., 42, 273-285, 2007.

Ashok, K., Guan, Z., Saji, N. H., and Yamagata, T.: Individual and combined influences of ENSO and the Indian Ocean Dipole on the Indian summer monsoon, J. Climate, 17, 3141-3155, 2004.

Bhalme, H. N. and Mooley, D. A.: Large-Scale Droughts/Floods and Monsoon Circulation, Mon. Weather Rev., 108, 1197-1211, 1980.

Cai, W., Zheng, X.-T., Weller, E., Collins, M., Cowan, T., Lengaigne, M., Yu, W., and Yamagata, T.: Projected response of the Indian Ocean Dipole to greenhouse warming, Nat. Geosci., 6, 999-1007, 2013.

Chowdhury, M. R. and Ward, M. N.: Hydro-meteorological variability in the greater Ganges-Brahmaputra-Meghna basins, Int. J. Climatol., 24, 1495-1508, 2004.

Chowdhury, M. R. and Ward, M. N.: Seasonal flooding in Bangladesh - variability and predictability, Hydrol. Process., 21, 335-347, 2007.

Das, P. K., Chakraborty, A., and Seshasai, M. V. R.: Spatial analysis of temporal trend of rainfall and rainy days during the Indian Summer Monsoon season using daily gridded $\left(0.5^{\circ} \times 0.5^{\circ}\right)$ rainfall data for the period of 1971-2005, Meteorol. Appl., 21, 481-493, doi:10.1002/met.1361, 2013.

De, U. S., Dube, R. K., and Rao, G. S. P.: Extreme weather events over India in the last 100 years, J. Ind. Geophys. Union, 9, 173187, 2005.

Du, Y., Cai, W., and Wu, Y.: A new type of the Indian Ocean Dipole since the mid-1970s, J. Climate, 26, 959-972, 2013.

Goswami, B. N.: Interannual Variations of Indian Summer Monsoon in a GCM: External Conditions versus Internal Feedbacks, J. Climate, 11, 501-522, 1998.
Guilyardi, E., Wittenberg, A., Fedorov, A., Collins, M., Wang, C., Capotondi, A., Van Oldenborgh, G. J., and Stockdale, T.: Understanding El Niño in ocean-atmosphere general circulation models: progress and challenges, Bull. Am. Meteorol. Soc., 90, 325340, 2009.

Hofer, T. and Messerli, B.: Floods in Bangladesh h : history, dynamics and rethinking the role of the Himalayas, United Nations University Press, New York, 2006.

Hossain, M. A.: Annual flood report 2012, FFWC, BWDB, Dhaka, Bangladesh, 2012.

Immerzeel, W. W.: Historical trends and future predictions of climate variability in the Brahmaputra Basin, Int. J. Climatol., 28, 243-254, 2008.

Kaplan, A., Cane, M., Kushnir, Y., Clement, A., Blumenthal, M., and Rajagopalan, B.: Analyses of global sea surface temperature 1856-1991, J. Geophys. Res., 103, 567-589, 1998.

Khalil, G.: Floods in Bangladesh: A question of disciplining the rivers, Nat. Hazard., 3, 379-401, 1990.

Kumar, K. K., Rajagopalan, B., and Cane, M. A.: On the weakening relationship between the Indian monsoon and ENSO, Science, 284, 2156-2159, 1999.

Kumar, K. K., Rajagopalan, B., Hoerling, M., Bates, G., and Cane, M.: Unraveling the mystery of Indian monsoon failure during El Nino, Science, 314, 115-119, 2006.

Luo, J.-J., Masson, S., Behera, S. K., and Yamagata, T.: Extended ENSO predictions using a fully coupled ocean-atmosphere model, J. Climate, 21, 84-93, 2008a.

Luo, J. J., Behera, S., Masumoto, Y., Sakuma, H., and Yamagata, T.: Successful prediction of the consecutive IOD in 2006 and 2007, Geophys. Res. Lett., 35, L14S02, doi:10.1029/2007GL032793, 2008 b.

Meyers, G., McIntosh, P., Pigot, L., and Pook, M.: The years of El Niño, La Niña and interactions with the tropical Indian Ocean, J. Climate, 20, 2872-2880, 2007.

Mirza, M. Q.: Climate Change, flooding in South Asia and implications, Environ. Change, 11, 95-107, 2011.

Mirza, M. Q., Warrick, R. A., Ericksen, N. J., and Kenny, G. J.: Are floods getting worse in the Ganges, Brahmaputra and Meghna basins?, Global Environ. Change Part B: Environ. Hazards, 3, 37-48, 2001.

Moors, E. J., Groot, A., Biemans, H., Van Scheltinga, C. T., Siderius, C., Stoffel, M., Huggel, C., Wiltshire, A., Mathison, C., Ridley, J., Jacob, D., Kumar, P., Bhadwal, S., Gosain, A., and Collins, D. N.: Adaptation to changing water resources in the Ganges Basin, northern India, Environ. Sci. Pol., 14, 758-769, 2011.

Pervez, M. S. and Henebry, G. M.: Projections of the GangesBrahmaputra precipitation - Downscaled from GCM predictors, J. Hydrol., 517, 120-134, 2014.

Rajeevan, M., Bhate, J., and Jaswal, A. K.: Analysis of variability and trends of extreme rainfall events over India using 104 years of gridded daily rainfall data, Geophys. Res. Lett., 35, L18707, doi:10.1029/2008GL035143, 2008

Rajkumar, G. and Narasimha, R.: Statistical analysis of the position of the monsoon trough, Proc. Indian Acad. Sci., 105, 343-355, 1996.

Ramesh, K. V. and Goswami, P.: Reduction in temporal and spatial extent of the Indian summer monsoon, Geophys. Res. Lett., 34, L23704, doi:10.1029/2007GL031613, 2007. 
Rao, S. A., Behera, S. K., Masumoto, Y., and Yamagata, T.: Interannual subsurface variability in the tropical Indian Ocean with a special emphasis on the Indian Ocean Dipole, Deep Sea Res. Part II: Topical Studies in Oceanography, 49, 1549-1572, 2002.

Rayner, N. A., Parker, D. E., Horton, E. B., Folland, C. K., Alexander, L. V., Rowell, D. P., Kent, E. C., and Kaplan, A.: Global analyses of sea surface temperature, sea ice, and night marine air temperature since the late nineteenth century, J. Geophys. Res., 108, 4407, doi:10.1029/2002JD002670, 2003.

Reynolds, R. W., Rayner, N. A., Smith, T. M., Stokes, D. C., and Wang, W.: An improved in situ and satellite SST analysis for climate, J. Climate, 15, 1609-1625, 2002.

Rodell, M., Velicogna, I., and Famiglietti, J. S.: Satellite-based estimates of groundwater depletion in India, Nature, 460, 999-1002, 2009.

Saji, N. and Yamagata, T.: Possible impacts of Indian Ocean dipole mode events on global climate, Clim. Res., 25, 151-169, 2003.

Saji, N. H., Goswami, B. N., Vinayachandran, P. N., and Yamagata, T.: A dipole mode in the tropical Indian Ocean, Nature, 401, 360363, 1999.

Schneider, U., Becker, A., Finger, P., Meyer-Christoffer, A., Rudolf, B., and Ziese, M.: GPCC Full Data Reanalysis Version 6.0 at $0.5^{\circ}$ : Monthly Land-Surface Precipitation from Rain-Gauges built on GTS-based and Historic Data, doi:10.5676/DWD_GPCC/FD_M_V6_050, 2011

Schott, F. A., Xie, S. P., and McCreary, J. P.: Indian Ocean circulation and climate variability, Rev. Geophys., 47, RG1002, doi:10.1029/2007RG000245, 2009.

Siddique, A. K., Baqui, A. H., Eusof, A., and Zaman, K.: 1988 floods in Bangladesh: pattern of illness and causes of death, J. Diarrhoeal Diseas. Res., 9, 310-314, 1991.

Sooraj, K. P., Kug, J., Li, T., and Kang, I.: Impact of El Niño onset timing on the Indian Ocean: Pacific coupling and subsequent El Niño evolution, Theor. Appl. Climatol., 97, 17-27, 2009.

Stocker, T., Dahe, Q., Plattner, G., Alexander, L., Allen, S., Bindoff, N., Breon, F., Church, J., Cubasch, U., Emori, S., Forster, P., Friedlingsteri, P., Gillett, N., Gregory, J. M., Hartmann, D. L., Jansen, E., Kirtman, B., Knutti, R., Krishna Kumar, K., Lemke, P., Marotzke, J., Masson-Delmotte, V., Meehl, G. A., Mokhov, I. I., Piao, S., Ramaswamy, V., Randall, D., Rhein, M., Rojas, M., Sabine, C., Shindell, D., Talley, L. D., Vaughan, D. G., and Xie, S.-P.: Technical Summary, in: Climate Change 2013: The Physical Science Basis. Contribution of Working Group I to the Fifth Assessment Report of the Intergovernmental Panel on Climate Change, edited by: Stocker, T. F., Qin, D., Plattner, G.-K., Tignor, M., Allen, S. K., Boschung, J., Nauels, A., Xia, Y., Bex, V., and Midgley, P. M., Cambridge University Press, Cambridge, United Kingdom and New York, NY, USA, 33-115, 2013.
Thenkabail, P. S., Biradar, C. M., Noojipady, P., Dheeravath, V., Li, Y., Velpuri, M., Gumma, M., Gangalakunta, O. R. P., Turral, H., Cai, X., Vithanage, J., Schull, M. A., and Dutta, R.: Global irrigated area map (GIAM), derived from remote sensing, for the end of the last millennium, Int. J. Remote Sens., 30, 3679-3733, 2009.

Trenberth, K. E.: The Definition of El Niño, Bull. Am. Meteorol. Soc., 78, 2771-2777, 1997.

Ummenhofer, C. C., England, M. H., McIntosh, P. C., Meyers, G. A., Pook, M. J., Risbey, J. S., Gupta, A. S., and Taschetto, A. S.: What causes southeast Australia's worst droughts?, Geophys. Res. Lett., 36, L04706, doi:10.1029/2008GL036801, 2009.

Ummenhofer, C. C., Gupta, A. S., Briggs, P. R., England, M. H., McIntosh, P. C., Meyers, G. A., Pook, M. J., Raupach, M. R., and Risbey, J. S.: Indian and Pacific Ocean influences on southeast Australian drought and soil moisture, J. Climate, 24, 1313-1336, 2011a.

Ummenhofer, C. C., Gupta, A. S., Li, Y., Taschetto, A. S., and England, M. H.: Multi-decadal modulation of the El Nino-Indian monsoon relationship by Indian Ocean variability, Environ. Res. Lett., 6, 034006, doi:10.1088/1748-9326/6/3/034006, 2011b.

UN-HABITAT: Mitigation, management and control of floods in South Asia, Risk and disaster management, Unitied Nationas Human Settlements Programme and United Nations Environment Programme, Nairobi, Kenya, 2002.

UNEP: Chief Liquidity Series, Water-related materiality briefings for financial institutions, United Nations Environment Programme, Switzerland, 2009

Webster, P. J., Moore, A. M., Loschnigg, J. P., and Leben, R. R.: Coupled ocean-atmosphere dynamics in the Indian Ocean during 1997-98, Nature, 401, 356-360, 1999.

Webster, P. J., Jian, J., Hopson, T. M., Hoyos, C. D., Agudelo, P. A., Chang, H. R., Curry, J. A., Grossman, R. L., Palmer, T. N., and Subbiah, A. R.: Extended-range probabilistic forecasts of Ganges and Brahmaputra floods in Bangladesh, Bull. Am. Meteorol. Soc., 91, 1493-1514, 2010.

Yamagata, T., Behera, S. K., Luo, J. J., Masson, S., Jury, M. R., and Rao, S. A.: Coupled ocean - atmosphere variability in the tropical Indian Ocean, in: Earth's Climate, edited by: Wang, C., Xie, S.-P., and Carton, J. A., American Geophysical Union, Washington D.C., 1-23, 2004.

Zheng, X.-T., Xie, S.-P., Vecchi, G. A., Liu, Q., and Hafner, J.: Indian Ocean Dipole Response to Global Warming: Analysis of Ocean-Atmospheric Feedbacks in a Coupled Model*, J. Climate, 23, 1240-1253, 2010. 